\title{
Vanadium Oxide Monolayer Catalysts \\ I. Preparation, Characterization, and Thermal Stability
}

\author{
By F. Roozeboom, 'T. Fransen, P. Mars, and P. J. Gellings
}

Enschede (The Netherlands), Department of Chemical Engineering, Twente University of Technology

Abstract. Vanadium oxide catalysts of the monolayer type have been prepared by means of chemisorption of vanadate $(V)$-anions from aqueous solutions and by chemisorption of gaseous $\mathrm{V}_{2} \mathrm{O}_{3}(\mathrm{OH})_{4}$. Using $\mathrm{Al}_{2} \mathrm{O}_{3}, \mathrm{Cr}_{2} \mathrm{O}_{3}, \mathrm{TiO}_{2}, \mathrm{CeO}_{2}$ and $\mathrm{ZrO}_{2}$, catalysts with an approximately complete monomolecular layer of vanadium( $V$ ) oxide on the carrier oxides can be prepared, if temperature is not too high. Divalent metal oxides like $\mathrm{CdO}$ and $\mathrm{ZnO}$ may already form threedimensional surface vanadates at moderate temperature.

The thermal stability of a monolayer catalyst is related to the parameter $z / a, j$. e. the ratio of the carrier cation charge to the sum of ionic radii of carrier cation and oxide anion. Thus, monolayer catalysts will be thermally stable only under the condition that $z / a$ is not too high (aggregated catalyst) nor too small (ternary compound formation).

\section{Vanadiumoxid Monoschichtkatalysatoren. I. Darstellung, Charakterisierung und thermische Stabilität}

Inhaltsübersicht. Durch Chemisorption von Vanadat(V)-Anionen aus wäßrigen Lösunger, bzw. Chemisorption von gasförmigem $\mathrm{V}_{2} \mathrm{O}_{3}(\mathrm{OH})_{4}$ wurden Vanadinoxidkatalysatoren des Mono-

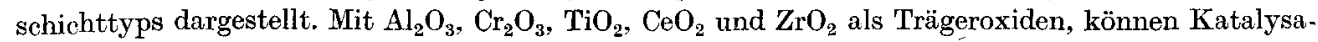
toren mit einer ungefähr vollständigen monomolekularen Schicht von Vanadin(V)-Oxid auf den Trägeroxiden dargestellt werden, falls die Temperatur nicht zu hoch ist. Zweiwertige Metalloxide wie z. B. CdO und $\mathrm{ZnO}$ können schon bei niedriger Temperatur dreidimensionale Oberflächenvanadate bilden.

Die thermische Stabilität eines Monoschichtkatalysators ist verbunden mit dem Parameter z/a: dem Quotient der Ladung des Trägerkations und der Summe der Ionenradien von Trägerkation und Oxidanion. Monoschichten werden thermisch nur stabil sein, falls $\mathrm{z} / \mathrm{a}$ nicht zu groß (aggregierter Katalysator) und nicht zu klein (Bildung einer ternären Verbindung) ist.

\section{Introduetion}

Vanadium oxides have been used extensively as catalysts in gas phase oxidation of hydrocarbons. In spite of extensive studies [1-12] the interpretation of the role of vanadium in the mechanisms of catalytic oxidations is still contradictory.

One of the problems is the difficulty in discriminating between surface atoms and the atoms in the interior of the oxide phase.

HANke et al. [13] suggested that more favourable conditions for studying the role of transition metal ions as active centres may be present, if the metal 
oxide can be obtained as a monomolecular layer, in which all atoms are dispersed on a carrier material. In this case all atoms may take part in catalytic reactions. However, the active component is chemically influenced by the carrier, i. e., it has an intimate contact with the latter species without loosing its surface character. This is reflected by the stability towards certain reactions of the monolayer vana$\operatorname{dium}(\mathrm{V})$ oxide compared to pure $\mathrm{V}_{2} \mathrm{O}_{5}$, such as reduction by hydrocarbons [11, 14] and dissolution in aqueous ammonia [14].

The chemical influence of the carrier is not necessarily a disadvantage: by carrier selection the selectivity and activity may be influenced [15]. Thus, the importance of monolayer catalysts is based on the large surface area exposed per amount of active component and on the influence of the carrier on catalytic activity and selectivity.

However, monolayer formation and monolayer stability are limited and depend strongly on the nature of the carrier and on temperature.

There is a variety of possible interactions between carrier and vanadium oxide:

a) Formation of crystallites of the active component.

b) Formation of a molecular dispersion of the active component (monolayer).

c) Formation of a new bulk compound.

d) Diffusion of the vanadium into the carrier (solid solution).

In preparing monolayer catalysts it is essential that no ternary compounds of the type $\mathrm{M}_{\mathrm{x}} \mathrm{V}_{\mathrm{y}} \mathrm{O}_{\mathrm{z}}$ (which we shall call a three dimensional "salt") nor solid solutions are formed between the two oxides by interdiffusion of the cations. Otherwise the active component might already disappear from the surface during annealing of the eatalysts.

In Fig. 1 a scheme is given of the various combinations of two oxides in order of increasing interaction (or affinity) (see also [16]). As this interaction, if any, often concerns the formation of very thin surface layers on the catalyst it is usually difficult to study or even to detect [17]. Only in a few cases this problem can be solved to a greater or lesser extent by using a combination of advanced experimental techniques.

This paper deals with the preparation and thermal stability of $V(V)$ oxide "monolayers" supported on some carrier oxides. We tried to obtain these with maximum monolayer coverage. In [16] it is argued that the trend in stabilities as found by heating mechanical mixtures may also apply to the stabilities of monolayer catalysts. Thus, equimolar mixtures of $\mathrm{V}_{2} \mathrm{O}_{5}$ (Merck, reagent grade) and some relevant oxides were prepared. Their thermal behaviour was studied by GuinierLenné X-ray analysis.

A theoretical background of the thermal stability of monolayer catalysts is also given. 
a

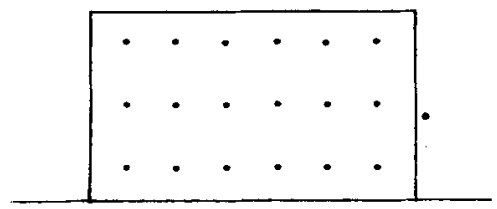

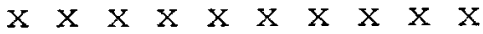

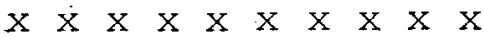

C

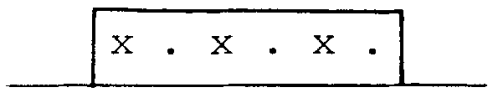

$\mathrm{x} x \cdot \mathrm{x} \cdot \mathrm{x} \cdot \mathrm{x} \mathrm{x}$

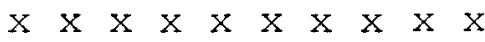

b

(1)

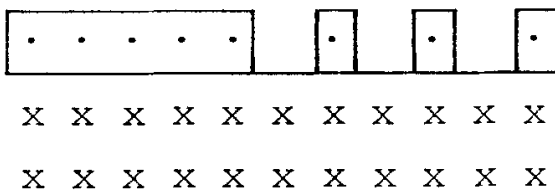

d

$\cdot \mathrm{x} \cdot \mathrm{x} \cdot \mathrm{x} \cdot \mathrm{x} \cdot \mathrm{x}$
$\mathrm{x} \cdot \mathrm{x} \cdot \mathrm{x} \cdot \mathrm{x} \cdot \mathrm{x} \cdot \mathrm{x}$
$\cdot \mathrm{x} \cdot \mathrm{x} \cdot \mathrm{x} \cdot \mathrm{x} \cdot \mathrm{x} \cdot$

Fig. 1 Classification of oxidic binary catalysts. a) aggregated catalyst, b) monolayer catalysts; (1) full coverage; (2) dispersion, c) "two-dimensional salt", d) three-dimensional salt or solid solution. It should be noted that there exists no absolute demarcation between the distinct structures, but only a gradual transition

\section{Experimental Methods}

Preparative methods

There exist several methods for the fixation of vanadium as a monolayer or a monomolecular dispersion. One is the preparation via adsorption of organovanadium compounds [18]. Another method is via reaction of surface hydroxyl groups with vanadium halides (e. g. $\mathrm{VCl}_{4}$ in the method of CHIEN [19]) or oxyhalides (e. g. $\left.\operatorname{VOCl}_{3}[13,20]\right)$. Another usual method is the impregnation of the carrier by a solution of vanadium ions $[14,21]$.

On the basis of our experience in preparing molybdenum oxide monolayer catalysts $[16,22]$ we tried to prepare vanadium oxide monolayer catalysts by adsorption of a gaseous hydroxide, $\mathrm{V}_{2} \mathrm{O}_{3}(\mathrm{OH})_{4}$, (gas phase synthesis), which is obtained from vanadium pentoxide at high temperatures and high partial pressures of water vapour [23].

We also tried to prepare monolayer catalysts by adsorption of vanadate ions from acid solution on the carrier in a dynamic system (liquid phase synthesis).

The formation of vanadium-isopolyanions by protonation and condensation of species with a lower degree of polymerization is well known [24]. An increase in $\mathrm{pH}$, as well as a decrease in the vana- 
dium concentration, decreases the polymerization. At $\mathrm{pH}<1$ vanadyl cations $\left(\mathrm{VO}_{2}{ }^{+}\right)$are the major solute components besides the, more or less protonated, threedimensional decavanadates. Near $\mathrm{pH} \approx 7$ the twodimensional tetra- and trivanadates are mainly formed. Di- and monovanadates are formed only above $\mathrm{pH}=9$ and $\mathrm{pH}=13$, respectively, that is, in a region in which a considerable decrease of surface area or even dissolution of the carrier may take place [14, 21].

The vanadium concentration at which vanadium pentoxide precipitates spontaneously on one side and the acid or alkali sensitivity of the carrier oxides for dissolution on the other side permit only a limited range of V-concentration and $\mathrm{pH}$.

With all these considerations in mind we used an aqueous solution of $1 \%$ (by weight) ammonium vanadate, acidified by nitric acid to $\mathrm{pH} \approx 4$. In this region the major solute component will be $\left[\mathrm{HV}_{10} \mathrm{O}_{28}\right]^{5-}$, a threedimensional decavanadate anion with low charge per vanadium atom [24, 25]. It takes more than 24 hours before spontaneous precipitation of $\mathrm{V}_{2} \mathrm{O}_{5}$ from this solution is observed.

\section{Results}

Liquid phase preparation

In Table 1 a summary is given of some physical parameters of the catalysts prepared by the methods described above. Remarkable are the increase in BETsurface area of the zirconia supported catalyst and the decrease for the chromia supported one. The colours of the silica and alumina supported catalysts agree with those reported by Yoshida et al. [14].

In Figs. 2 and 3 typical plots are given for the concentration of vanadium and for the $\mathrm{pH}$ in the effluent as a function of time.

Apart from the experiments with silica all other experiments showed the same effect: the first fraction of the orange coloured solution of the feed was dis-

Table 1 Survey of prepared catalysts

\begin{tabular}{|c|c|c|c|c|c|c|c|c|}
\hline Sample & Catalyst & $\begin{array}{l}\text { Pre- } \\
\text { para- } \\
\text { tion }\end{array}$ & $\begin{array}{l}\text { amount } \\
\text { of } \\
\text { carrier } \\
\text { (grams) }\end{array}$ & $\begin{array}{l}\text { Surface } \\
\left(\mathrm{m}^{2} \cdot \mathrm{g}^{-1}\right) \\
\text { carrier }\end{array}$ & $\begin{array}{l}\text { area } \\
\text { cata- } \\
\text { lyst }\end{array}$ & $\begin{array}{l}\mathrm{V} \text {-con- } \\
\text { tent } \\
(\%)\end{array}$ & $\begin{array}{l}\Phi_{\mathrm{V}-\text { oxide }} \\
c \\
\left(10^{4} \mathrm{pm}^{2}\right)\end{array}$ & Colour $^{d}$ ) \\
\hline 1. & $\mathrm{~V}(\mathrm{~V})$-oxide $/ \mathrm{Al}_{2} \mathrm{O}_{3}$ & $\left.1^{a}\right)$ & 8.0 & 55 & 53 & 3.7 & 12 & greenish-yellow \\
\hline $\left.2^{b}\right)$ & $\mathrm{V}(\mathrm{V})$-oxide $/ \mathrm{Al}_{2} \mathrm{O}_{3}$ & 1 & & $\left.53^{b}\right)$ & 53 & 3.8 & 11.7 & greenish-yellow \\
\hline 3 & $\mathrm{~V}(\mathrm{~V})$-oxide/ $\mathrm{CeO}_{2}$ & 1 & 6.1 & 70 & 50 & 3.4 & 12.5 & yellow-orange \\
\hline 4 & $\mathrm{~V}(\mathrm{~V})$-oxide $/ \mathrm{Cr}_{2} \mathrm{O}_{3}$ & 1 & 4.8 & 140 & $2 \check{5}$ & 1.5 & 14 & green-black \\
\hline 5 & $\mathrm{~V}(\mathrm{~V})$-oxide $/ \mathrm{TiO}_{2}$ & 1 & 7.1 & 49 & 39 & 1.6 & 20 & creamy \\
\hline 6 & $\mathrm{~V}(\mathrm{~V})$-oxide $/ \mathrm{ZrO}_{2}$ & 1 & 11.7 & 150 & 250 & 9.3 & 23 & yellow-orange \\
\hline 7 & $V(V)$-oxide $/ \mathrm{SiO}_{2}$ & 1 & 3.2 & 350 & 350 & 1.1 & 270 & yellow-brown \\
\hline 8 & $\mathrm{~V}(\mathrm{~V})$-oxide $/ \mathrm{Al}_{2} \mathrm{O}_{3}$ & $\mathrm{~g}$ & 4.4 & 55 & 40 & 4.1 & 9 & greenish-orange \\
\hline
\end{tabular}

\footnotetext{
a) $1=$ liquid phase preparation and $\mathrm{g}=$ gas phase preparation

b) Sample 1 after a second liquid phase preparation

c) In crystallized $V_{2} \mathrm{O}_{5}, \Phi_{\mathrm{VO}_{2.5}}$ is 10.3 [13] to $10.95 \times 10^{4} \mathrm{pm}^{2}$ (from density calculations according to $[35])$

d) After drying at $110^{\circ} \mathrm{C}(8 \mathrm{~h})$ and calcination at $400^{\circ} \mathrm{C}(2 \mathrm{~h})$
} 
coloured when it left the carrier column. (Chromia gave a yellow green coloration, due to $\mathrm{Cr}^{3+}$ ).

The effluent gradually became more orange coloured, usually in less than $1 \mathrm{hr}$, depending on the amount of carrier used. More quantitatively this is reflected by the V-concentrations in Fig. 2, which after an extremely low value reach the original value of the feed ("break-through" of the vanadium). The total amounts of vanadium thus disappeared from the solution correspond with those present on the carrier oxides, as calculated from their $\mathrm{V}$-content and the amounts of carrier oxide, within 10 percent accuracy.

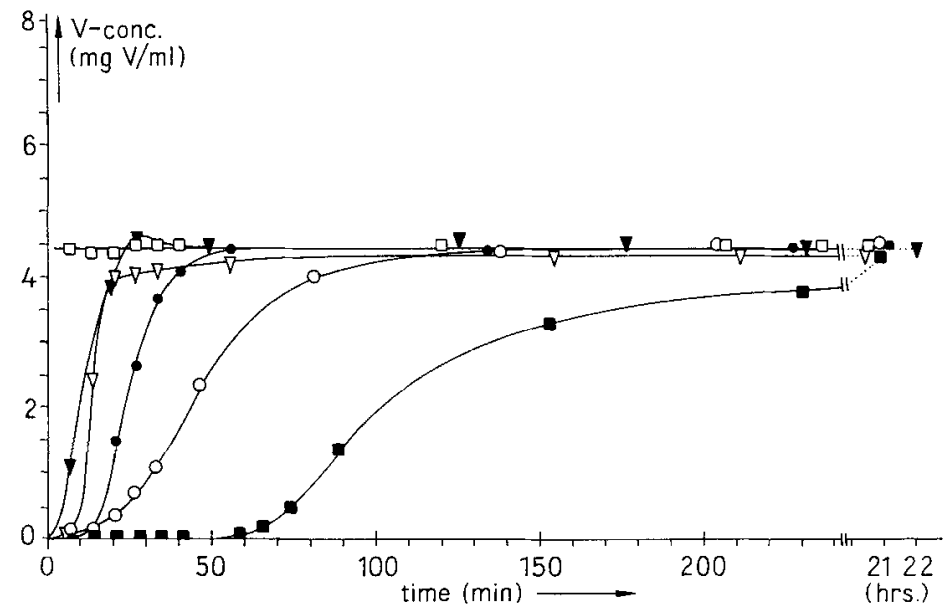

Fig. 2 Concentration of vanadium in the effluent as a function of time, during liquid phase preparation. $\circ \mathrm{Al}_{2} \mathrm{O}_{3} ; \mathrm{CeO}_{2} ; \square \mathrm{SiO}_{2} ; \mathrm{ZrO}_{2} ; \nabla \mathrm{TiO}_{2} ; \boldsymbol{\mathrm { Cr } _ { 2 } \mathrm { O } _ { 3 }}$

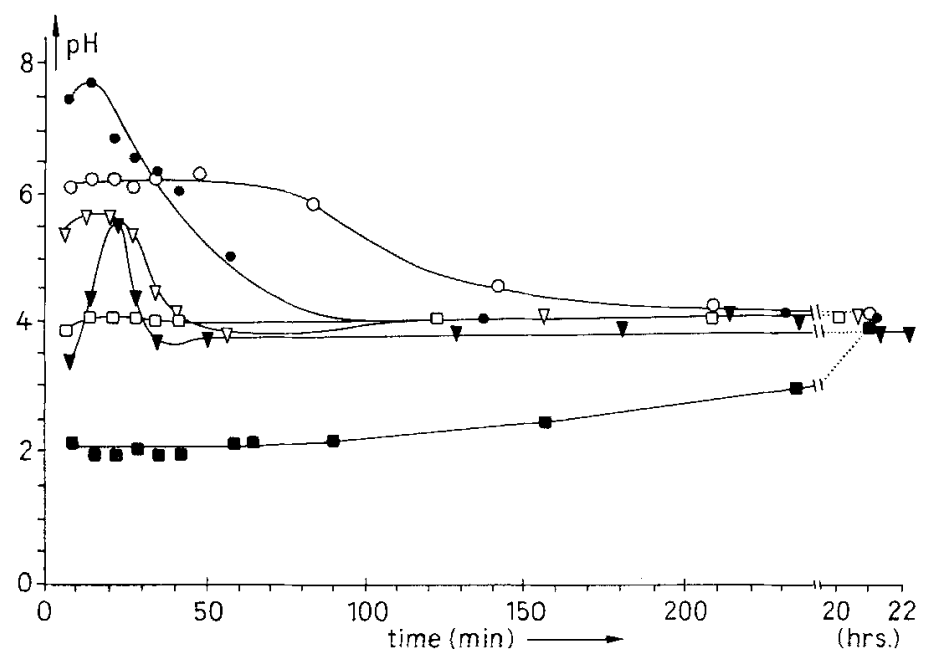

Fig. $3 \mathrm{pH}$ of the effluent as a function of time during liquid phase preparation (Symbols see Fig. 2) 


\section{Further observations are:}

a) The decrease in vanadium concentration is accompanied by a simultaneous increase in pH of the effluent (Fig. 3). A similar increase in $\mathrm{pH}$ is also reported by JANNIBELLo et al. for the chemisorption of molybdenum(VI) on $\gamma$-alumina under various preparative circumstances [26, 27]. The only anomaly in this respect is the zirconia supported catalyst which shows a decrease in pH. This is also shown very slightly, only in the beginning, by the chromia supported catalyst.

b) After preparation via adsorption the amount of $V$ present per surface area is, for all catalysts independent of the position in the adsorbent bed ${ }^{1}$ ) (Fig. 4) and of the adsorption time (Fig. 2 and Table 1).

c) For the alumina, ceria and chromia supported catalysts the calculated average surface area available per $\mathrm{V}(\mathrm{V})$ oxide unit $\left(\Phi_{\mathrm{V} \text {-oxide }}\right)$ has the same order of magnitude as the units in pure $\mathrm{V}_{2} \mathrm{O}_{5}$ (see Table 1) and those in the oxide carriers. The catalysts supported on titania and zireonia show higher values for $\Phi_{\mathrm{V} \text {-oxide, }}$, indicating a monolayer coverage which is not wholly complete. Exceptional is the behaviour of the silica supported catalyst. From the liquid phase only a very small amount adsorbs: $\Theta=0.05$.

d) In none of the catalysts, mentioned in Table 1, an X-ray diffraction pattern of $V_{2} O_{5}$ or any other $V$-containing phase could be detected.

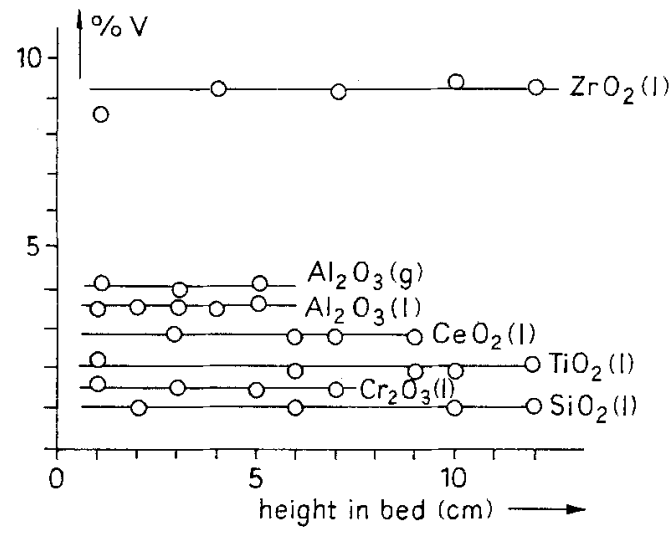

Fig. 4 Vanadium concentration profile in the beds after liquid phase (1) and gas phase (g) preparation

Preliminary ESCA-experiments on the vanadia/alumina catalyst (liquid phase prepared) showed that the oxide phases of vanadium and aluminium are strongly interacting. This is shown in Fig. 5, in which the photo-electron spectrum of the catalyst is plotted together with the spectrum of a physical mixture of both oxides, also with $3.7 \% \mathrm{~V}$. The shoulder of the $\mathrm{O}(1 \mathrm{~S})$ peak due to $\mathrm{V}_{2} \mathrm{O}_{5}$ (the spectrum for pure $\mathrm{V}_{2} \mathrm{O}_{5}$, as recorded by the same apparatus gives a binding energy of $529.9 \mathrm{eV}$ [28]) in the latter spectrum is absent in the former. This indicates that

1) Also on a micro-scale the vanadium seems to be uniformly dispersed. By means of an energy dispersive analyser of $\mathrm{X}$-rays (EDAX), attached to a scanning electron microseope (JSM-U3) we analysed a $300 \mu$ granule of $\mathrm{V}(\mathrm{V})$ oxide $/ \mathrm{Al}_{2} \mathrm{O}_{3}$ (liquid phase prepared) at an optical magnification of $300 \mathrm{X}$. A fine sean analysis over this granule revealed that at a constant level of the AlK $x$ signal $(1,486 \mathrm{KeV})$ the $\mathrm{VK} \alpha$ signal $(4,949 \mathrm{KeV})$ was constant within the statistical deviation. This technique will be used for further investigation of our catalysts. 
the upper layer(s) of the catalyst consist(s) of some other surface phase than $\mathrm{V}_{2} \mathrm{O}_{5}$. Unfortunately, the vanadium content of the silica-supported catalyst was too low to conduct an analogous ESCA study.
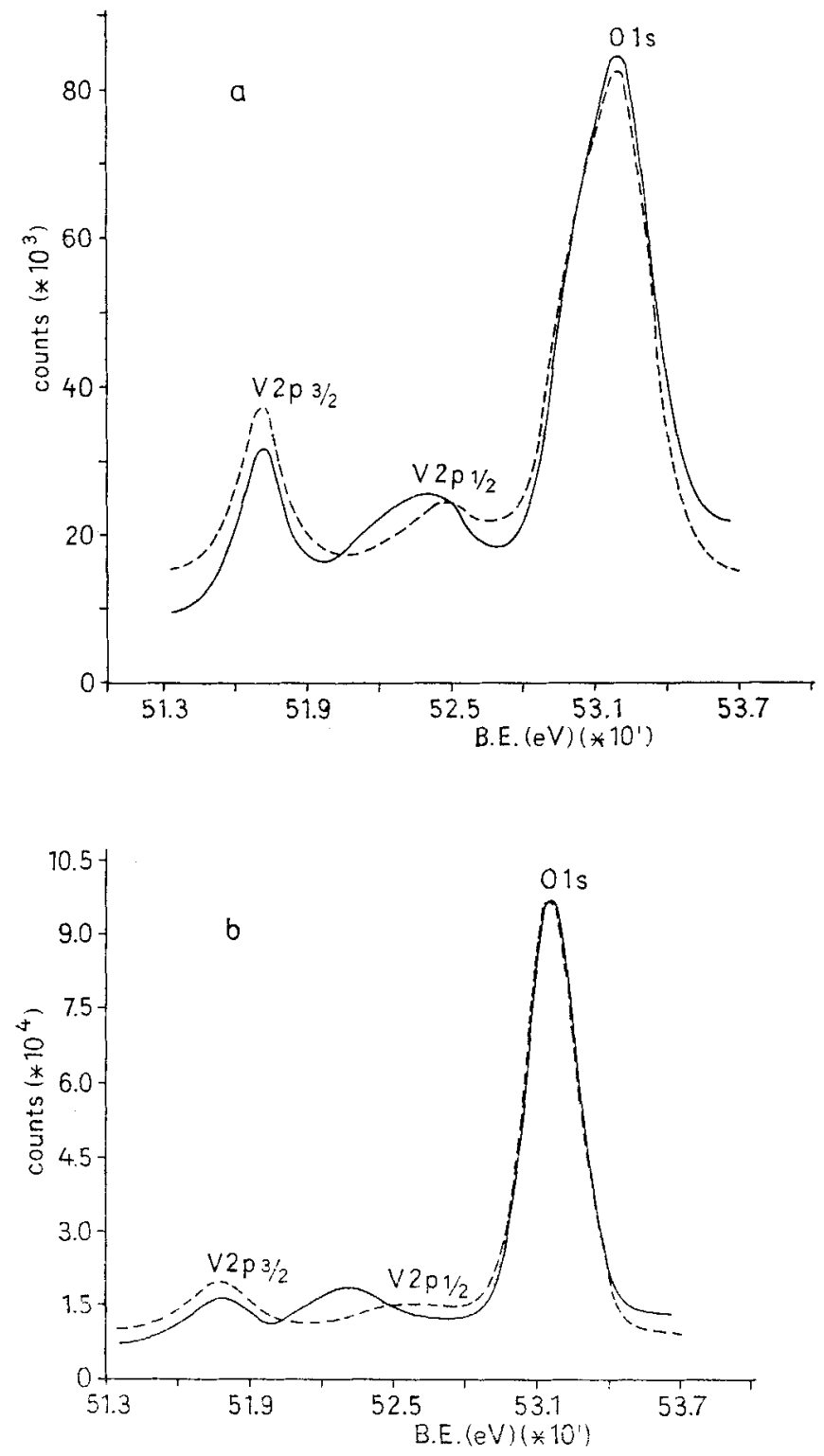

Fig. 5 X-ray photoelectron spectra of vanadia/alumina. a) physical mixture of $\mathrm{V}_{2} \mathrm{O}_{5} / \mathrm{Al}_{2} \mathrm{O}_{3}, 3.7 \% \mathrm{~V}$ b) liquid phase prepared catalyst $\mathrm{V}(\mathrm{V})$-oxide $/ \mathrm{Al}_{2} \mathrm{O}_{3}, 3.7 \% \mathrm{~V}$ (-- -.) recorded spectra; (_- -) spectra corrected for background, analyzer-transmission and satellite peaks 
Gas phase preparation

When the experiment was stopped before the vanadium oxide reached the last alumina particles, a sharp green-brown front of $\mathrm{V}(\mathrm{V})$-oxide could be observed. This indicates that the adsorption of the oxide or hydroxide is very strong. After "breakthrough" the vanadium oxide recrystallized as bright orange needles in the colder parts of the reactor tube. From Fig. 4 it follows that here also the vanadium content is constant throughout the bed: $4.1 \pm 0.1 \% \mathrm{~V}$. The same applies for the BET surfaces $(40 \pm 2) \mathrm{m}^{2} / \mathrm{g}$. X-ray diffraction reveals only peaks of $\delta, \gamma$ and some $-\mathrm{Al}_{2} \mathrm{O}_{3}$ and no peaks for $\mathrm{V}$ compounds. If again a monomolecular layer of vanadium oxide is assumed the calculated surface area occupied by one $\mathrm{V}(\mathbf{V})$ oxide unit (about $9 \times 10^{4} \mathrm{pm}^{2}$ ) agrees very well with the "theoretical" value (see Table 1).

Heating of mechanical mixtures

The results of heating $\mathrm{V}_{2} \mathrm{O}_{5}$, mechanically mixed with carrier oxides, are listed in 'Table 2, which gives an indication of the salt formation in these systems. For the mixtures of $\mathrm{V}_{2} \mathrm{O}_{5}$ with $\mathrm{SiO}_{2}, \mathrm{TiO}_{2}, \mathrm{SnO}_{2}$ and $\mathrm{MoO}_{3}$ no change in the diffraction patterns was observed up to $800^{\circ} \mathrm{C}$. For the other mixtures the observed diffraction patterns are described in Table 2.

Table 2 Salt formation on heating equimolar mechanical mixtures of $\mathrm{V}_{2} \mathrm{O}_{5}$ and (carrier) oxides

\begin{tabular}{|c|c|c|c|}
\hline Carrier & z/a of cation ${ }^{2}$ ) & $\begin{array}{l}\text { Ninimun temperature } \\
\text { of salt formation }(K)\end{array}$ & $\begin{array}{l}\text { Observed diffraction } \\
\text { pattern }\end{array}$ \\
\hline $\mathrm{CdO}$ & 0.85 & 650 & $\mathrm{CdV}_{2} \mathrm{O}_{7}$ \\
\hline $\mathrm{ZnO}$ & 0.93 & 660 & $\mathrm{ZnV}_{2} \mathrm{O}_{7}$ \\
\hline $\mathrm{CoO}$ & 0.94 & 87.5 & c) \\
\hline $\mathrm{NiO}$ & 0.95 & 765 & c) \\
\hline $\mathrm{Fe}_{2} \mathrm{O}_{3}$ & 1.47 & 750 & $\mathrm{FeVO}_{1}$ \\
\hline $\mathrm{Cr}_{2} \mathrm{O}_{3}$ & 1.49 & 805 & $\mathrm{CrVO}_{4}$ \\
\hline $\mathrm{Al}_{2} \mathrm{O}_{3}$ & 1.55 & 880 & $\mathrm{AlVO}_{1}$ \\
\hline $\mathrm{CeO}_{2}$ & 1.69 & 675 & $\mathrm{CeVO}_{1}$ \\
\hline $\mathrm{ZrO}_{2}$ & 1.79 & 880 & $\mathrm{Zr}_{\mathrm{r}} \mathrm{V}_{2} \mathrm{O}_{7}$ \\
\hline $\mathrm{SnO}_{2}$ & 1.91 & b) & \\
\hline $\mathrm{TiO}_{2}$ & 1.99 & b) & \\
\hline $\mathrm{SiO}_{2}$ & 2.41 & b) & \\
\hline $\mathrm{MoO}_{3}$ & 3.00 & b) & \\
\hline
\end{tabular}

$\left.{ }^{a}\right) \mathrm{z} /\left(\mathrm{r}_{\text {cation }}+\mathrm{r}_{\mathrm{O}^{2}-}\right)$, see text. Use was made of the effective ionic radii of SHANNon and Prewit? [36] with coordination number 4 for Si, 8 for Ce and $\mathrm{Zr}$ and $i f$ for other cations.

b) No salt formation upto $1000 \mathrm{~K}$. $\quad$ c) Different vanadate phases.

\section{Diseussion}

Liquid phase preparation

The constant level of the $V$ content (Fig. 4), the absence of diffraction patterns of any $V$-containing phases and the value of $9-14 \times 10^{4} \mathrm{pm}^{2}$ obtained for the area of one $\mathrm{VO}_{2.5}$ unit on various carrier oxides (Tables 1 ) strongly suggest the presence 
of a monolayer of vanadium( $(V)$ oxide on the carriers used, except for silica. On titania and zirconia the $V(V)$ oxide may be present as a monomolecular dispersion, covering most of the available surface. Most of the silica surface will be uncovered, (compare also [29]), while it is unclear whether the $\mathrm{V}(\mathrm{V})$ oxide is present as a monomolecular dispersion or as crystallites. The minor difference of the value of $\Phi_{\mathrm{VO}_{2 \cdot 5}}$ on the other catalysts compared to $\Phi_{\mathrm{Vo}_{2.5}}$ in crystalline $\mathrm{V}_{2} \mathrm{O}_{5}\left(10.3 \cdot 10^{4} \mathrm{pm}^{2}\right.$ [13]) may be due to the hydration sphere of the anions, which disappear during heat treatment or due to the decomposition of the primarily adsorbed ammonium vanadate at temperatures greater than $200-300^{\circ} \mathrm{C}$ [29]. Another reason for this difference, especially in case of gas phase preparation, may be that the vanadium units are incorporated in such a way that the new structure forms a continuation. of the carrier oxide units, compare [22]. These crystallographic (mis)fits between vanadium oxides and a carrier oxide are further a subject of a recent study [30] on a vanadia/titania catalyst.

Figs. 2 and 3 show that the increase on $\mathrm{pH}$ coincides with a decrease in the $\mathrm{V}$-concentration until the "breakthrough" of the vanadate solution. The increase in $\mathrm{pH}$, except for zirconia as the carrier, is in agreement with the non-stoichiometric reaction scheme proposed by HoRvath et al. [21]:

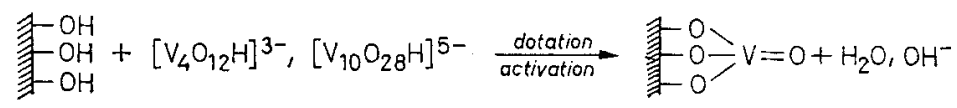

in which they suggest a depolymerization of the primarily adsorbed polyvanadate units into monomeric $\mathrm{V}(\mathrm{V})$ oxide units during the activation phase, i. e. annealing at elevated temperatures. In this stage also water is formed as a consequence of further condensation of the hydroxyl groups of the adsorbed vanadate species.

However, if the $\mathrm{V}$ would adsorb as a full layer of threedimensional decavanadate units, annealing would give a $\mathrm{V}$-content corresponding to a multilayer rather than a monolayer.

The fact that at $\mathrm{pH}=4$, used in this work, where even more decavanadate anions are present than at $\mathrm{pH}=7$ as chosen by HoRvath et al., a monolayer or a monomolecular dispersion is still formed, strongly suggests that at least part of the decavanadate already depolymerizes during the adsorption process. These may give smaller twodimensional species, e.g. tetra- and trivanadates or perhaps even smaller units. This is supported by the $\mathrm{pH}$ of the effluent, which showed values at which these two species are the major components [24]. Also JarNibeLLo and coworkers $[26,27]$ suggest an anionic exchange mechanism for the interaction between molybdenum(VI) and $\gamma$-alumina. They propose the chemisorption of monomeric Mo-species, that are formed by depolymerization just before chemisorption. Thus, we propose the following reactions to occur:

$$
\left.\begin{array}{l}
\text { a) }\left[\mathrm{HV}_{10} \mathrm{O}_{28}\right]^{-5} \rightleftharpoons \mathrm{V}_{10} \mathrm{O}_{28}^{6-}+\mathrm{H}^{+} \\
\text {b) } 2 \mathrm{~V}_{10} \mathrm{O}_{28}^{6-}+9 \mathrm{H}_{2} \mathrm{O} \rightleftharpoons 5 \mathrm{~V}_{4} \mathrm{O}_{13}^{6-}+18 \mathrm{H}^{+} \\
\text {c) } \mathrm{V}_{4} \mathrm{O}_{13}^{6-}+\mathrm{H}_{2} \mathrm{O} \rightleftharpoons 2 \mathrm{~V}_{2} \mathrm{O}_{7}^{4-}+2 \mathrm{H}^{+} \\
\text {d) } \mathrm{V}_{2} \mathrm{O}_{7}^{4-}+\mathrm{H}_{2} \mathrm{O} \rightleftharpoons 2 \mathrm{VO}_{4}^{3-}+2 \mathrm{H}^{+}
\end{array}\right\} \begin{aligned}
& \text { Stage (I): } \\
& \text { depolymerizotion }
\end{aligned}
$$




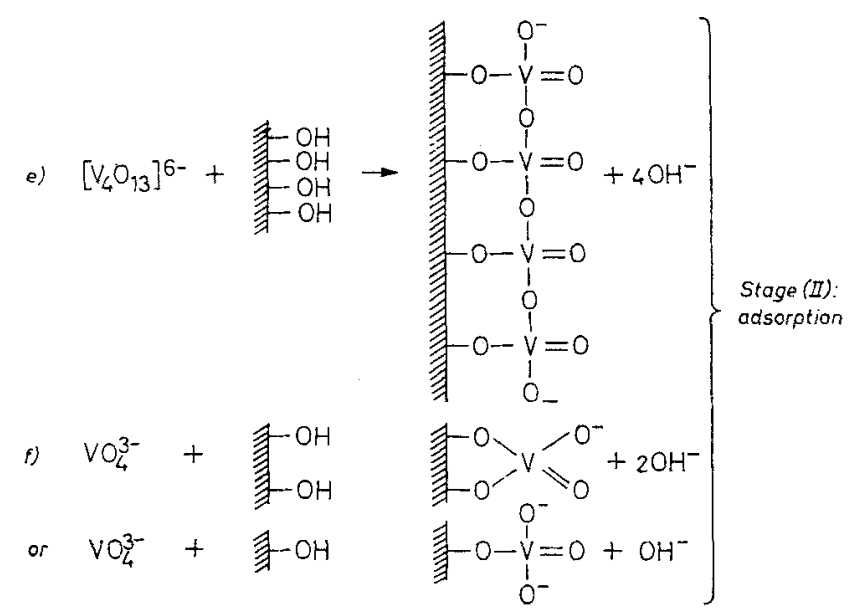

In the case of zirconia, which has a great microporosity [31], stage (I) may possibly occur up to the monomeric species, $\mathrm{VO}_{4}{ }^{3-}$, only these being small enough to fit into these micropores. In this way more protons are evolved in stage (I) than hydroxyl groups are exchanged in stage (II). Of course this is only a schematic representation of the adsorption and may differ in detail from the real situation.

This affinity of zirconia for especially monomeric species produces an acid solution ( $\mathrm{pH} \sim 2$, Fig. 3) which passes the bed of a basic oxide. Thus the BET-surface (Table 1) may be increased since zirconyl ions will dissolve. Some equilibria in stage I are slow reactions [24]. As the breakthrough of this oxide is also anomalously long, this may indicate that the depolymerization takes place during adsorption and that depolymerization and adsorption are coupled.

In case of the other carriers depolymerization may occur not further than the twodimensional tetravanadate. Thus the $\mathrm{pH}$ will be determined by stage (II). During annealing further depolymerization may take place as proposed by Horvarm et al. [21].

\section{Gas phase preparation}

The calculated average surface area $\Phi_{\mathrm{V} \text {-oxide }}$ of about $9 \times 10^{4} \mathrm{pm}^{2}$ suggests a vary high degree of coverage on the alumina. The strong chemical interaction between the vanadium oxide and the aluminium oxide is reflected by the observed $\Theta$-alumina phase which is already formed at $600^{\circ} \mathrm{C}$.

This is in accordance with the findings of Shevrakov et al, who studied the influence of vanadium oxide concentration on the rate of the polymorphic transformation of alumina by XRD and IR spectroscopy [32]. They ascribe the stabilizing action of small quantities of $\mathrm{V}_{2} \mathrm{O}_{5}$ on $\mathrm{Al}_{2} \mathrm{O}_{3}$ during heat-treatment to a chemical interaction between both oxides and propose the origination of an interstitial solid solution. This may also explain the slightly too "low" value of $9 \times 10^{4} \mathrm{pm}^{2}$ for $\Phi_{\text {V-oxide }}$, as found by us.

\section{Heating of mechanical mixtures}

As a parameter for the ease with which two solid oxides will react to salt formation the expression

$$
\frac{z_{c}}{r_{c}+r_{o}} \equiv \frac{z}{a}
$$


may be introduced. Its value for the various oxides is mainly influenced by $\mathrm{z}_{\mathbf{c}}$ and $r_{c}$, the charge and the radius of the carrier cation, respectively. $r_{0}$ is the ionic radius of oxygen.

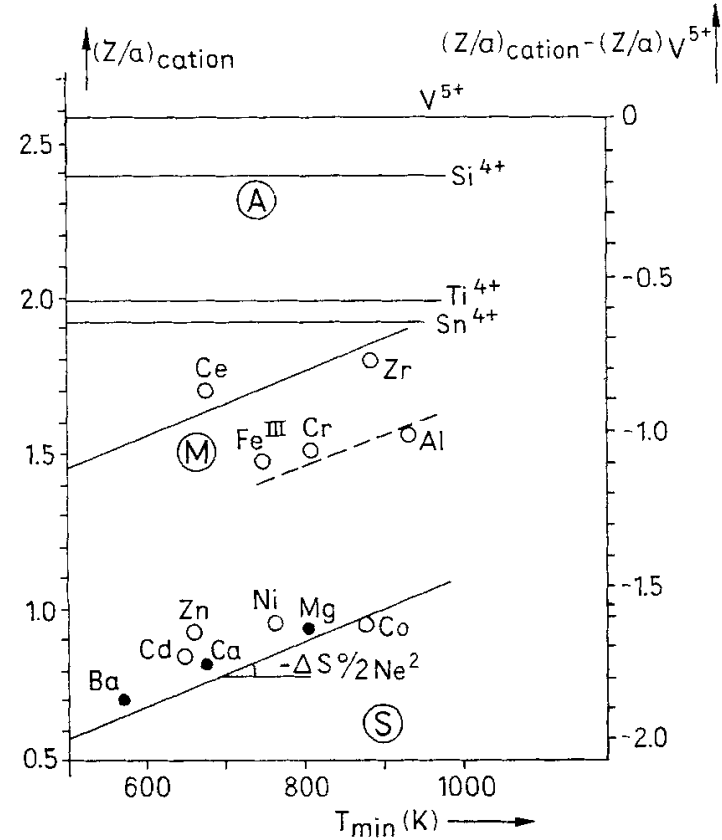

Fig. 6

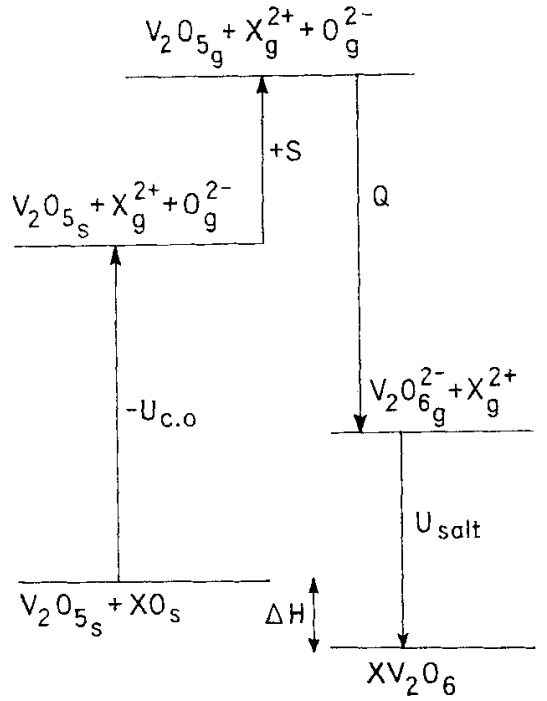

Fig. 7

Fig. $6 \mathrm{z} / \mathrm{a}$ values of the cation $\mathrm{X}^{\mathrm{n}+}$ versus the minimum temperature of salt formation in equimolar mixtures of $\mathrm{XO}_{\mathrm{n} / 2}$ and $\mathrm{V}_{2} \mathrm{O}_{5}$. See also Table 2. Minimum temperatures for the alkaline earth metals are taken from lit. [34]. Solid lines roughly represent the boundaries between the main regions $\mathrm{S}, \mathbf{M}$ and $\mathrm{A}$

Fig. 7 Born-Haber cycle for the salt formation of $\mathrm{XV}_{2} \mathrm{O}_{6}$

If the expression for $\mathrm{z} / \mathrm{a}$ of the various oxides is plotted against the minimum temperature of salt formation of the corresponding vanadates three main regions can be distinguished as shown in Fig. 6: (see also ref. [16]) $\mathrm{S}$, if $\mathrm{z} / \mathrm{a}$ is too low, salt formation may already occur at temperatures at which catalytic activities usually are determined; $A$, if $\mathrm{z} / \mathrm{a}$ is too high, it seems that the affinity of the carrier oxides (e. g. $\mathrm{SiO}_{2}$ ) for salt formation or even a full monolayer coverage is too low; $\mathrm{M}$, for intermediate $\mathrm{z} / \mathrm{a}$ values, where monolayer catalysts can be stable.

Making use of other parameters, which also reflect the affinity of the carrier oxide to the active component, for instance their Pauling electronegativities, or their ionic field strengths $\left(\mathrm{z} / \mathrm{a}^{2}\right)$ [33], similar conclusions are reached.

The background for this general piature may be the thermodynamics of salt formation and/or the kinetics of this process. From thermodynamics it follows that compound formation for the reaction

$$
\mathrm{XO}+\mathrm{V}_{2} \mathrm{O}_{5} \rightarrow \mathrm{XV}_{2} \mathrm{O}_{6}
$$


may occur if

$$
A G^{\circ}=A H^{\circ}-\mathrm{T} A \mathrm{~S}^{\circ} \leq 0 .
$$

If it is assumed that the minimum temperature of salt formation, $T_{m}$, is close to the equilibrium of this reaction, the relation

$$
\Delta \mathrm{H}^{\circ}=\mathrm{T}_{\mathrm{m}} \cdot \Delta \mathrm{S}^{\circ}
$$

is valid.

The energetics of salt formation is visualized in a Born-Haber cycle as presented in Fig. 7. It is assumed there that an $\mathrm{O}^{2-}$ anion is donated to a $\mathrm{V}_{2} \mathrm{O}_{5}$ unit, yielding $\mathrm{Q} \mathrm{kJ} \cdot \mathrm{mol}^{-1}$. The reaction enthalpy then is

$$
A \mathrm{H}^{\circ}=\mathrm{U}_{\mathrm{e} . \mathrm{o}}-\mathrm{Q}-\mathrm{U}_{\mathrm{salt}}+\mathrm{S}
$$

where $\mathrm{U}_{c, 0}$ and $\mathrm{U}_{\mathrm{salt}}$ (calculated on the basis of combination of $\mathrm{X}^{2+}$ and $\mathrm{V}_{2} \mathrm{O}_{6}{ }^{2-}$ ions) are the lattice energies of the carrier oxide and of the salt, respectively and $S$ is the sublimation energy of $\mathrm{V}_{2} \mathrm{O}_{5}$. As the $\mathrm{V}_{2} \mathrm{O}_{6}{ }^{2-}$ ion is much larger than the $\mathrm{O}^{2-}$ ion $\mathrm{U}_{\text {salt }} \ll \mathrm{U}_{\text {c.o }}$ and may be neglected. Thus, in a first approximation

$$
\Delta \mathrm{H}^{\circ}=\mathrm{U}_{\mathrm{c} . \mathrm{O}}-\mathrm{Q}+\mathrm{S}
$$

in which $Q$ is independent of the nature of the cation $\mathrm{X}^{2+}$. For purely ionic compounds, when taking into account only nearest neighbour interactions, we have

$$
U_{c . o}=-N \cdot \frac{z_{c} z_{o} \cdot e^{2}}{r_{c}+r_{o}}=-N \frac{z_{c} z_{0} \cdot e^{2}}{a}
$$

in which $\mathrm{N}$ is Arogadro's number, $\mathrm{z}_{c}, \mathrm{z}_{\mathrm{o}}$ and $\mathrm{r}_{\mathrm{c}}, \mathrm{r}_{\mathrm{o}}$ are the charges and the radii of the cation and $\mathrm{O}^{2-}$, respectively.

Combining equations (1), (2) and (3) gives

$$
\mathrm{T}_{\mathrm{m}} \cdot \Delta \mathrm{S}^{\circ}=-2 \mathrm{~N} \cdot \mathrm{e}^{2}(\mathrm{z} / \mathrm{a})-\mathrm{Q}+\mathrm{S} \text {. }
$$

Our measurements, as presented in Fig. 6, also show a roughly linear relationship between $\mathrm{z} / \mathrm{a}$ and $\mathrm{T}_{\mathrm{m}}$. The vanadates of $\mathrm{Ti}, \mathrm{Sn}$ and $\mathrm{Mo}$ ( $\mathrm{z} / \mathrm{a}$-values larger than about 1.9) have neither been detected by us, nor have they been reported in the literature.

It is remarkable that the observed linear relationship, applies very well to the distinct groups of cations, but less to all valence groups together. If one would also take into account some effects of the different crystal structures of the carriers, for instance by including next-neighbour interaction, the right-hand term in equations (3) and (4) would contain the parameter $\mathbf{M} \cdot(\mathrm{z} / \mathrm{a})$. Here $\mathbf{M}$ is the Madelung constant. If this parameter is plotted in Fig. 6 instead of the simple $\mathrm{z} / \mathrm{a}$ parameter, however, the lines are shifted even more apart. Still structural effects of the carrier remain important [30].

Our simplified thermodynamic picture (see also [16]) has more limitations, e. g., it is not applicable to the formation of solid solutions or to the case that the salt is very stable $\left(\Delta \mathrm{H}^{\circ} \ll 0\right)$. Moreover the slope of the experimental "lines" in Fig. 6, corresponding to - $\Delta \mathrm{S}^{\circ}\left(2 \mathrm{Ne}^{2}\right)^{-1}$, gives unexpected values: from our experiments we calculate a value of about $-2500 \mathrm{~J} \cdot \mathrm{K}^{-1} \cdot \mathrm{mole}^{-1}$ which is larger than 
$4 \mathrm{~S}^{\circ}$ values of about $-550 \mathrm{~J} \cdot \mathrm{K}^{-1} \cdot$ mole $^{-1}$ reported for the metavanadates of the alkaline earth metals [34]. This means that other factors must play an important role in salt formation, such as kinetic factors, compare also [30]. The rate of diffusion will in general increase with a lower stability of the carrier oxide because then both the defect concentration and the mobility will be higher. Also this rate will be proportional to the gradient of the chemical potential of the diffusing species, which decreases with increasing thickness of the product layer. If $\Delta \mathrm{G}^{\circ}$ is assumed to be a linear function of $\mathrm{z} / \mathrm{a}$, i. e. $\Delta \mathrm{G}^{\circ}=\mathrm{c}_{1}+\mathrm{c}_{2} \cdot \mathrm{z} / \mathrm{a}$, the rate of salt formation is given by

$$
\mathbf{r}_{\mathrm{m}}=\mathbf{D}_{0} \cdot \mathrm{e}^{-\alpha \Delta \mathrm{G}^{\circ} / R \mathrm{~T}_{\mathrm{m}}} \cdot \mathrm{A}_{\mathrm{spec}} \cdot\left(\frac{\Delta \mu_{\mathrm{i}}}{\Delta \mathrm{z}}\right)
$$

in which $\mathrm{D}_{0} \cdot \mathrm{e}^{-\alpha \Delta \mathrm{G}^{\circ} / R \mathrm{RT}} \mathrm{m}=\mathrm{D}_{0} \cdot \mathrm{e}^{-\left(\mathrm{c}_{1}+\mathrm{c}_{2} \cdot(Z / \mathrm{a})\right) / \mathrm{RT}} \mathrm{m}$, the diffusion coefficient

$\mathrm{r}_{\mathrm{m}}=$ the minimum detectable reaction rate

$A_{\text {spec }}=$ the surface area of diffusion

$\Delta \mu_{\mathrm{i}} / \Delta \%=$ the gradient of the chemical potential of the diffusing species $\mathrm{i}$

and the activation enthalpy is assumed to be proportional to the $\Delta G^{\circ}$ of the oxide by a factor $\alpha$.

If changes in the nature and the number of defects in the different salts are not too large, it follows that

$$
\mathbf{T}_{\mathrm{m}} \cdot \mathbf{R} \cdot \ln \left[\frac{\mathrm{D}_{\mathbf{0}} \cdot \mathbf{A} \cdot \Delta \mu_{\mathrm{i}} / \Delta \mathrm{z}}{\mathbf{r}_{\mathrm{m}}}\right]=\alpha \Delta \mathrm{G}^{\circ}=\mathrm{c}_{\mathbf{1}}{ }^{\prime}+\mathrm{c}_{\mathrm{z}}{ }^{\prime} \cdot(\mathrm{z} / \mathrm{a}) .
$$

Now one may assume that the Guinier-Lenné camera measures the temperatures necessary to reach a detectable and equal rate of salt formation (i. e. $r_{m}=$ constant in all cases). This means that a relation is obtained similar to equation (4), derived from a thermodynamic point of view, provided that the logarithm of the gradient $\Delta \mu_{\mathrm{i}} / \Delta \mathrm{z}$ does not depend too much on the nature of the carrier oxide.

\section{Conclusions}

1) Complete or partial monolayer catalysts of vanadium(V)-oxide can be prepared via adsorption of vanadate ions from aqueous solutions and via adsorption of gaseous $\mathrm{V}_{2} \mathrm{O}_{3}(\mathrm{OH})_{4}$ at about $600^{\circ} \mathrm{C}$.

2) Vanadium oxide monolayer catalysts are stable in a relatively large temperature region for intermediate values of $\mathrm{z} / \mathrm{a}$, compared to that of $\mathrm{V}_{2} \mathrm{O}_{5}$. The fact that a rule of this type has been found to be applicable to Mo-oxide/carrier systems as well as the theoretical background show that this rule has a more general scope.

\section{Experimental}

\section{Liquid phase preparation}

In this preparation a fresh solution of $1 \%$ ammonium vanadate $(\mathrm{pH} \approx 4)$ was passed through a bed of carrier oxide particles $(0.3-0.6 \mathrm{~mm}, 2-20 \mathrm{~g}, \varnothing=80 \mathrm{ml} / \mathrm{h})$ in an apparatus which resembles that described in [37] except for the analy tcial part. The carrier oxides were prepared as described in [16]. At the outlet of the reactor, the $\mathrm{pH}$ and the vanadium concentration were determined. After this procedure, the catalyst bed was divided into some fractions, dried at $110^{\circ} \mathrm{C}(8 \mathrm{~h})$ and calcined at $400^{\circ} \mathrm{C}(2 \mathrm{~h})$. Then the vanadium content and the specific surface areas $\left(\mathrm{S}_{\mathrm{g}}\right)$ were determined. 


\section{Gas phase preparation}

Fig. 8 shows the apparatus with which a flow of air of $\sim 15 \mathrm{l} / \mathrm{h}$ was saturated with water vapour to a pressure of $49 \cdot 10^{3} \mathrm{~Pa}(0.5 \mathrm{~atm})$ as calculated from the amount of water condensed and the total air flow.

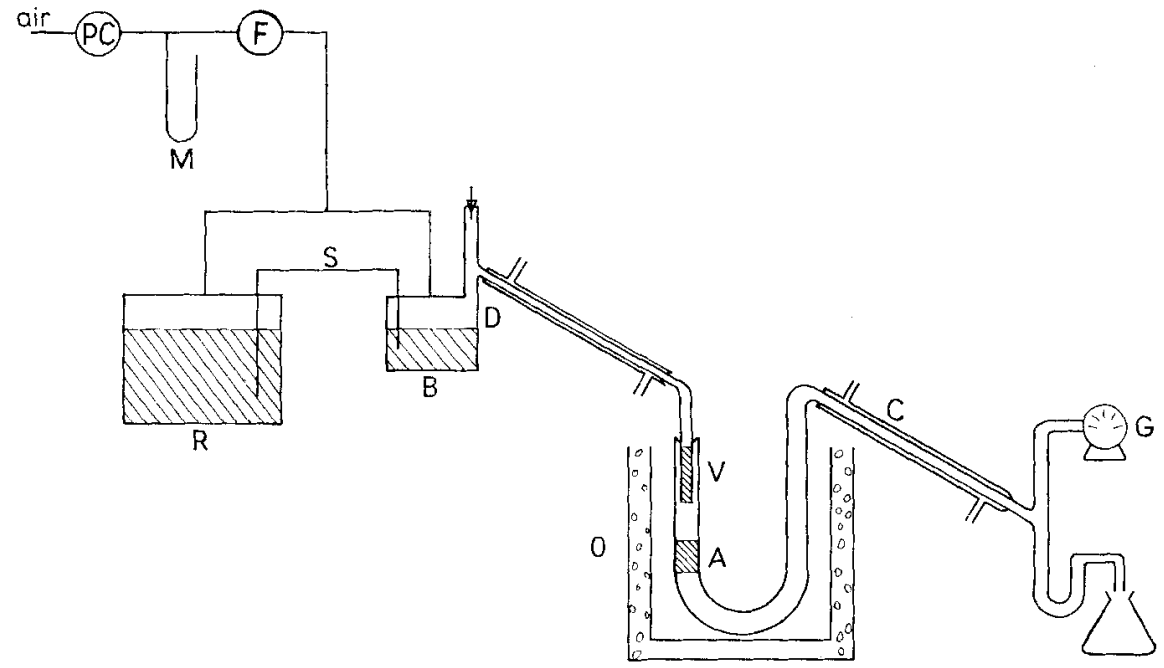

Fig. 8 Apparatus for gas phase preparation. $\mathrm{PC}=$ precision pressure controller, $\mathbf{M}=$ manometer, $\mathrm{F}=$ flow meter, $\mathrm{S}=$ siphon, $\mathrm{R}=$ = reservoir of distilled water, $\mathrm{B}=$ boiling vessel, $\mathrm{D}=$ destillation unit, heated up to $100^{\circ} \mathrm{C}, \mathrm{V}=\mathrm{V}_{2} \mathrm{O}_{5}$-bed, $\mathrm{A}=\mathrm{Al}_{2} \mathrm{O}_{3}$-bed, $\mathrm{O}=$ Oven, kept at $600^{\circ} \mathrm{C}, \mathrm{C}=$ condensor, $\mathrm{G}=$ gasmeter

The mixture was passed first through a bed of $\mathrm{V}_{2} \mathrm{O}_{5}$ particles previously molten and then crushed

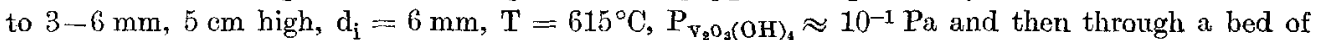
carrier oxide particles $\left(0.3-0.6 \mathrm{~mm}, 4\right.$ gram $\left.\mathrm{Al}_{2} \mathrm{O}_{3}, 5 \mathrm{~cm} \mathrm{high} ; \mathrm{d}_{\mathrm{i}}=12 \mathrm{~mm}, \mathrm{~T}=620^{\circ} \mathrm{C}\right)$. The pressure drop over the two beds was around $18 \mathrm{mbar}$. The temperature of the $\mathrm{V}_{2} \mathrm{O}_{5}$ was somewhat lower in order to prevent condensation of $\mathrm{V}_{2} \mathrm{O}_{5}$ between the vanadia and carrier (i. e. alumina) bed. The temperature of the varrier was constant within $2^{\circ} \mathrm{C}$.

Under these circumstances about 10 days were needed before the front of vanadium oxide broke through and formed fine $\mathrm{V}_{2} \mathrm{O}_{5}$ crystals in the colder part of the reactor outlet. After this preparation the catalyst bed was divided into some fractions. The vanadium content of these fractions and their surface areas were determined (see analysis) as well as their X-ray diffraction patterns.

\section{Analysis}

The vanadium concentration in solutions was determined (after acidifying with sulfuric acid) by titration with a Mohr's salt solution. The vanadium content of catalyst samples was determined by $\mathrm{X}$-ray fluorescence [38]. Surface areas of the catalysts were calculated by means of the BET-equation from the adsorption isotherm of argon at $77.3 \mathrm{~K}$ (the cross sectional area of an argon atom was taken to be $13.8 \times 10^{4} \mathrm{pm}^{2}$ and $\mathrm{p}_{0}$ as $0.30 \cdot 10^{5} \mathrm{~Pa}$ ). Use was made of the apparatus, described by Bosci et al. [39]. Finally the catalyst samples were studied by X-ray diffraction.

\section{Heating of mechanical mixtures}

Equimolar mixtures of $\mathrm{V}_{2} \mathrm{O}_{5}$ (Merck, reagent grade) and the respective carrier oxides were prepared by grinding in a ball mill. These mixtures were heated slowly $\left(\sim 5^{\circ} \mathrm{C} / \mathrm{h}\right)$ in a Guinier-Lenné camera (Enraf Nonius), which registered the diffraction patterns (CuK $\alpha$ radiation) continuously as a function of temperature. 
ESCA spectra were obtained with the aid of an AEI-ES-200 spectrometer equipped with a glove box, kept under a dry nitrogen atmosphere.

The samples were placed into the glove box and, not powdered, mounted on adhesive tape.

Use was made of the X-ray excitation from $\mathrm{MgK} \alpha(1253.6 \mathrm{eV})$ with a line width of $0.7 \mathrm{eV}$.

The spectrometer was evacuated to better than $7 \cdot 10^{-6} \mathrm{~Pa}$ and the data were collected with $\mathrm{a}$ PDP-8/e computer. The spectra were recorded at $180 \mathrm{Watt}$ source power, while the sample temperature was between -10 to $+10^{\circ} \mathrm{C}$. A C(1S) value of $285.0 \mathrm{eV}$ [40] for the surface carbon contaminant was used in the energy calibration of the spectra. The data of each spectrum were corrected for analyser-transmission, backscattering and satellite peaks (phenomenon of double excitation) by means of a computer program.

This study was supported by the Netherlands Foundation for Chemical Research (SON) with aid from the Netherlands Organization for the Advancement of Pure Research (ZWO). Thanks are due to G. A. SAwatzky and A. Herres (Laboratory of Physical Chemistry, University of Groningen) for recording the XPS-spectra and help in the interpretation, to J. BoEIJsMA for recording X-ray diffraction patterns.

\section{References}

[1] P. Mars and D. W. vax Krevelen, Spec. Suppl. Chem. Eng. 3, 41 (1954).

[2] V. A. Roiter and V. A. Yuza, Kinet. Katal. 3, 343 (1962).

[3] H. Schateer, Ber. Bunsenges. Phys. Chem. 71, 222 (1967).

[4] W. H. M. Sachtler, Catal. Rev. 4, 27 (1970).

[5] V. J. Marshneva, G. K. Boreskov and V. D. Sokolovski, Kinet. Katal. 13, 393 (1972).

[6] V. J. Marshieva, G. K. Boreskov and V. D. Sokolovski, Kinet. Katal. 13, 1209 (1972).

[7] O. V. Krylov, Kinet. Katal. 14, 34 (1973).

[8] M. N. Colpaeri, Z. Phys. Chem. (Frankfurt/M.), \$4, 10 0 (1973).

[9] S. Yoshima, T. Matsuzaki, S. Ishida and K. Tamara, Proc. Fifth Int. Congr. Catal., vol. 2, p. 1049, North Holland Publ. Co., Amsterdam 1973.

[10] M. YA. Kon, V. A. Shvets and V. B. KAZANskIr, Kinet. Katal. 14, 303 (1973).

[11] E. I. Andreikov, Yu. A. Sveshrimova and N. D. Rusyanova, Kinet. Katal. 17, 639 (1976).

[12] M. YA. Kov, A. M. Gritskov, V. A. Shvers and V. B. Kazanskm, Kinet. Katal. 17, 958 (1976).

[13] W. Hanke, R. Bienfre and H. G. Jerschiewiz, Z. anorg. allg. Chem. 414, 109 (1975).

[14] S. Yoshida, T. Iguchi, S. Ishidd and K. Tamara, Bull. Chem. Soc. Jap. 45, 367 (1972).

[15] M. S. Wain Wright and T. W. Hoffmann, Can. J. Chem. Eng. 55, 557 (1977).

[16] T. Fransex, P. C. vax Berge and P. Mars, in: "Preparation of Catalysts" (B. Dramos, P. A. Jacobs, G. Poncelet, Ed.), p. 405, Elsevier Sci. Publ. Comp., Amsterdam 1976.

[17] G. T. Potr and W. H. J. Stonk, in: "Preparation of Catalysts" (B. Delmon, P. A. Jacobs, G. Poncelet, Ed.), p. 537, Elsevier Sci. Publ. Comp., Amsterdam 1976.

[18] Yu. I. Yenuakov, Catal. Rèv. 13, 77 (1976).

[19] J. C. W. Chiex, J. Amer. Chem. Soc. 93, 4675 (1971).

[20] A. A. Malygin, A. N. Volkova, S. I. Kolzov and W. B. Aleskovser, Zh. Obshch. Khim. 43, $1436(1973)$.

[21] B. Horvath, J. Geyer and H. L. Krauss, Z. anorg. allg. Chem. 426, 141 (1976).

[22] J. Sonnemans and P. Mars, J. Catal. 31, 209 (1973).

[23] O. GLemser and A. Müller, Z. anorg. allg. Chem. 325, 220 (1963).

[24] M. T. Pope and B. W. DALE, Quart. Rev, (London) 29, 527 (1968).

[25] S. E. O'Donnelu and M. T. Pope, J. Chem. Soc., Dalton Trans. 21, 2290 (1976).

[26] A. Jannibello and F. Trifiro, Z. anorg. allg. Chem. 118, 293 (1975).

[27] A. Jannibello, S. Marexgo, V. Berti, P. Villa and F. Trifiro, Can. J. Chem. Eng. 55, 747 (1977). 
[थ8] D. Post, E. Antonides and G. A. Sawatzky, to be published.

[29] L. N. Vorobev, I. K. Badalova, F. G. Kamaev and G. Sh. Talipov, Zh. Obshch. Khim. 47, $1832(197 \overline{)})$.

[30] A. Vejux, P. Covrtive, J. Solid State Chem. 28, 93 (1978).

[31] H. Th. Rijnteis, Thesis, Delft University of Technology 1971. Jansen, Nijmegen, The Netherlands.

[32] A. M. Shevyakov, I. P. Methengov, C. V. Cherepkov, E. A. Vlasov and E. G. Semis, Dokl. Akad. Nauk SSSR, $\mathbf{2 9 9}, 360$ (1976).

[33] A. Dietzel and H. Tober, Ber. Deut. Keram. Ges. 30, 71 (1953).

[34] Gmelin s Handbuch der anorganischen Chemie, number 48, part B2, pp. 506, 513, Verlag Chemie, Weinheim 1967.

[35] P. H. Enumetr and S. Brovatfr, J. Amer. Chem. Soc. 59, 1503 (1937).

[36] R. D. Shannon and C. T. Prewitw, Acta Crystallogr. B25, 925 (1969).

[37] A. V. Rodionov, V. K. Duflyakin and M. E. Levinter, Zh. Fiz. Khim. 51, 990 (1977).

[38] J. H. H. G. van Wrutigex, H. Krumhof and F. A. M. F. Dahmen, Talanta 18, 450 (1971).

[39] H. Boscr and A. Pepprezengos, J. Phys. E. Sci. Instr. 10, 605 (1977).

[40] G. Johassos, J. Hedian, A. Bersdtsson, M. Klasson and R. Nilssox, J. Electron. Spectrosc. Relat. Phenom. 2,295 (1973).

Bei der Redaktion eingegangen am 29. Mai 1978.

Anschr, d. Verf.: F. Roozerooir, Dr. T. Frassey, Prof. Dr. P. Mans und Prof. Dr. P. J. Gellings, Techn. Hogeschool Twente, Afd. d. Chemische Technologie, Postbus 217, i500 AE Enschede (Nederland) 